\title{
Developing New Coastal Forest Restoration Products Based on Landsat, ASTER, and MODIS Data
}

\author{
J. P. Spruce \\ Science Systems \& Applications, Inc. \\ Bldg 1105, Room 117G \\ Stennis Space Center, MS 39529 \\ J. Smoot \\ Science Systems \& Applications, Inc. \\ Bldg 1105, Room 124G \\ Stennis Space Center, MS, 39529 \\ W. Graham \\ NASA Applied Science \& Technology Project Office \\ Bldg 1100, Room 2005G, Mail Code PA30 \\ Stennis Space Center, MS, 39529
}

\begin{abstract}
This paper discusses an ongoing effort to develop new geospatial information products for aiding coastal forest restoration and conservation efforts in coastal Louisiana and Mississippi. This project employs Landsat, Advanced Spaceborne Thermal Emission and Reflection Radiometer (ASTER), and Moderate Resolution Imaging Spectroradiometer (MODIS) satellite data in conjunction with airborne elevation data to compute coastal forest cover type maps and change detection products. Improved forest mapping products are needed to aid coastal forest restoration and management efforts of State and Federal agencies in the Northern Gulf of Mexico (NGOM) region. In particular, such products may aid coastal forest land acquisition and conservation easement procurements. This region's forests are often disturbed and subjected to multiple biotic and abiotic threats, including subsidence, salt water intrusion, hurricanes, sea-level rise, insect-induced defoliation and mortality, altered hydrology, wildfire, and conversion to non-forest land use. In some cases, such forest disturbance has led to forest loss or loss of regeneration capacity. In response, a case study was conducted to assess and demonstrate the potential of satellite remote sensing products for improving forest type maps and for assessing forest change over the last 25 years. Change detection products are needed for assessing risks for specific priority coastal forest types, such as live oak and baldcypress-dominated forest. Preliminary results indicate Landsat time series data are capable of generating the needed forest type and change detection products. Useful classifications were obtained using 2 strategies: 1) general forest classification based on use of 3 seasons of Landsat data from the same year; and 2) classification of specific forest types of concern using a single date of Landsat data in which a given targeted type is spectrally distinct compared to adjacent forested cover. When available, ASTER data was useful as a complement to Landsat data. Elevation data helped to define areas in which targeted forest types occur, such as live oak forests on natural levees. MODIS Normalized Difference Vegetation Index time series data aided visual assessments of coastal forest damage and recovery from hurricanes. Landsat change detection products enabled change to be identified at the stand level and at 10year intervals with the earliest date preceding available change detection products from the National Oceanic and Atmospheric Administration and from the U.S. Geological Survey. Additional work is being done in collaboration with State and Federal agency partners in a follow-on NASA ROSES project to refine and validate these new, promising products. The products from the ROSES project will be available for aiding NGOM coastal forest restoration and conservation.
\end{abstract}

\section{INTRODUCTION}

A case study was performed in which Landsat, the Advanced Spaceborne Thermal Emission and Reflection Radiometer (ASTER), and the Moderate Resolution Imaging Spectroradiometer (MODIS) satellite data were used in conjunction with airborne elevation data to produce coastal forest type maps and change detection products. Additional introductory information on the project background and relevant published literature is given below. 


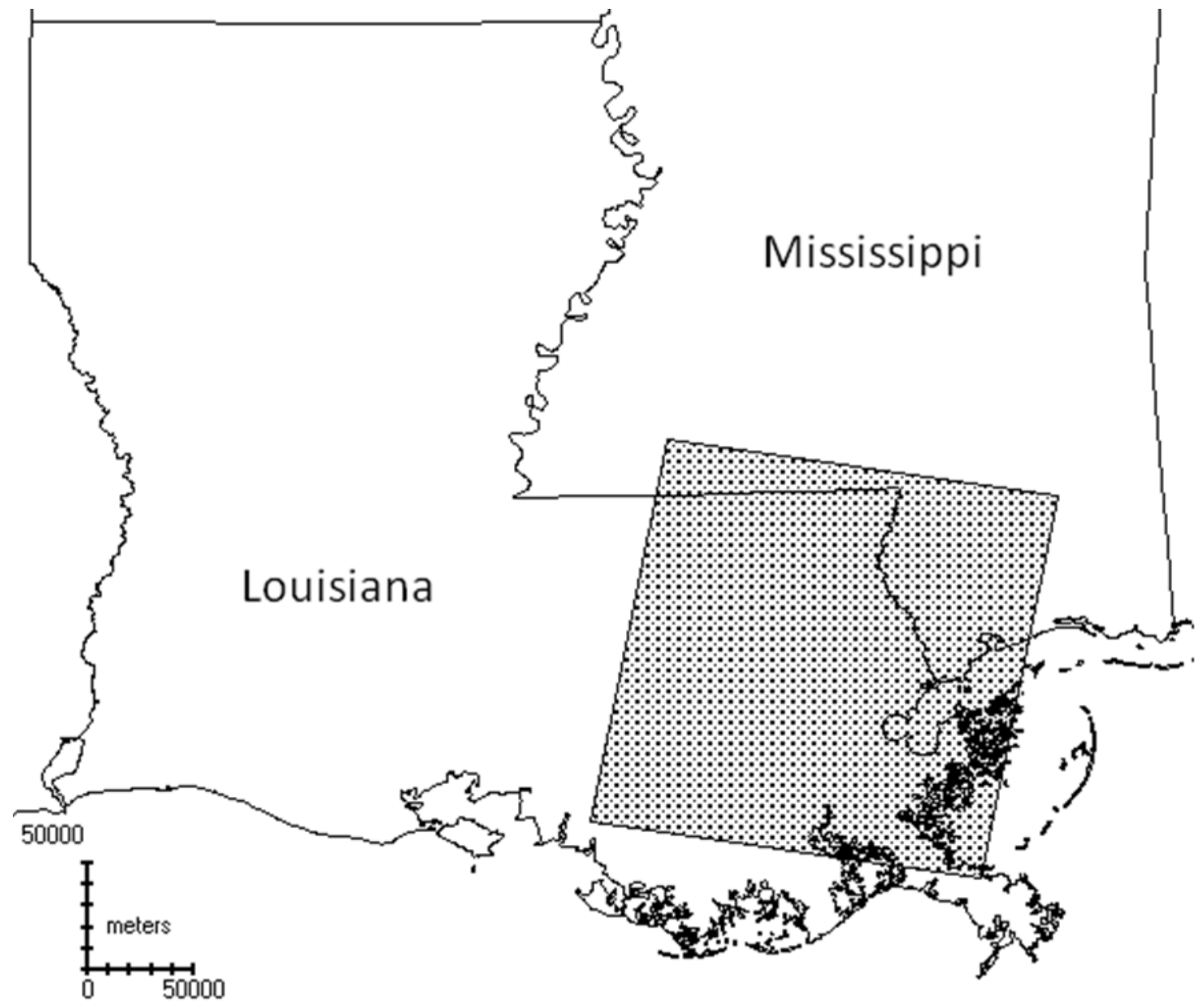

Fig 1. Location of study area (shaded square) in relation to Louisiana. The square area denotes the footprint of Landsat 5 path 22 row 39.

\section{A. Project Background}

Coastal forests in the Northern Gulf of Mexico (NGOM) coastal forests are subjected to numerous threats and are at risk of being non-sustainable in areas subject to coastal land loss. Coastal forests in this region usually occur on wetland sites. The sites with sufficiently high elevations to be designated non-wetland (or truly upland) are more likely to be employed for other land uses, such as agriculture and urban uses. NASA-supported remote sensing products have become increasingly used in addressing coastal zone management issues of the region and offers potential for aiding coastal forest restoration and conservation efforts that are underway. In particular, synoptic remote sensing data from Landsat, ASTER, and MODIS satellite sensors have potential for producing new NGOM coastal forest type maps and change detection products that could be utilized for aiding restoration and conservation of these forests.

In response, a series of projects have been underway to explore, validate, and demonstrate the potential of NASA satellite data for aiding coastal forest monitoring of NGOM. Initially, this project focused on the coastal forests of Louisiana. This paper discusses results obtained for a region that includes Lake Maurepas, Lake Pontchartrain, Lac des Allemandes, Lake Verret, and Lake Palourde in Louisiana. This area falls within path 22 row 39 of the Landsat WRS-2 grid (Fig. 1). Coastal vegetation types in this region tend to vary in relation to subtle elevational gradients. The lowest elevations tend to be marsh dominated. Upland from marsh, most of the lower elevation forests are occupied by baldcypress, water tupelo, or mixed cypress/tupelo swamps. Higher elevation, predominantly wetland forests occur on natural levee, chenier, salt domes, and beach ridge landforms. The elevations in this region's coastal deltaic plain tend to be 5 feet or less and infrequently exceed 15 feet. Subsidence, sea level rise, and coastal erosion are frequently evident along the shorelines of the larger lakes. This phenomenon is contributing to forest decline and mortality. 
An in-house feasibility study was first performed to assess if satellite remote sensing data could be applied to improve maps on coastal swamp forests of Louisiana. This work included literature review supplemented with a limited amount of experimentation with actual satellite datasets. This work provided evidence that use of satellite remote sensing data for this application was indeed technically feasible and led to a proposal to the NASA Roses A.28 solicitation. This proposal, "Use of NASA satellite data to improve coastal cypress forest management" was recently funded with a start-up date of September 2009. While the ROSES A.28 proposals were being evaluated, a follow-on case study was conducted to assess use of NASA-supported satellite data for mapping and monitoring higher elevation NGOM coastal forests. The results of this case study are the focus of this paper. This work is in essence a hands-on feasibility demonstration study that occurred from February through August 2009.

The project was conducted in collaboration with Louisiana Department of Natural Resources (LDNR), the US Army Corps of Engineers, the US Geological Service (USGS), the Barataria Terrebonne National Estuary Program, the Louisiana Department of Environmental Quality, and the Nature Conservancy. Additional partnerships with Louisiana State University and the USDA Forest Service are also being pursued. Products from this work will be available for aiding the LDNR Coastal Forest Conservation Initiative and the USGS Northern Gulf of Mexico Ecosystem Change and Hazard Susceptibility Project. These partnerships and related activities are also relevant to the follow-on NASA ROSES project on coastal cypress forest monitoring.

This work was funded primarily through NASA's Applied Sciences program and encompasses multiple Gulf of Mexico Alliance issues, especially wetland and coastal conservation restoration. It is most relevant to the agriculture, ecological forecasting, and disaster management application areas of NASA's Applied Sciences Program.

In the case study specific to this paper, the two primary objectives are to 1) assess results of using NASA science data products to revise available base maps of Louisiana coastal forest occurring in higher elevation landforms, such as levees, cheniers, and barrier islands; and 2) assess results of using NASA science data products to quantify changes in Louisiana coastal forests growing on levees, cheniers, and barrier islands.

In addressing these objectives, a combination of satellite and airborne data were used to develop and assess coastal forest mapping products. Lidar data were used to improve satellite-base classifications of higher elevation coastal forests, as separate from lower elevation marsh and swamp forests. Multispectral satellite data were subsequently used to detect and assess higher elevation forest types (e.g., coastal live oak forest). Disturbances of these forests were assessed using MODIS, Landsat, and ASTER data.

\section{B. Relevant Previous Work on Coastal Higher Elevation Forests of Louisiana}

The coastal plains of Louisiana include multiple higher elevation landforms that are usually forested and can include live oak forests. These landforms include natural levees, cheniers, and elevated beach strands of barrier islands. The elevation of these infrequently flooded forests is still relatively flat and low at $\sim 1$ to 6 meters mean sea-level, although it is higher than adjacent semi-permanently flooded swamp forests and nearby marshland. In this region, subtle micro-topographic changes (expressed in inches or a few feet) can separate one coastal land cover type from another. The Bayou Villars area [1] water table was measured at $\sim 2$ feet below the ground-level natural levee live oak forests, whereas the water table was estimated at 6 inches above the ground level of cypress-tupelo swamp forest. These higher elevation coastal forests are vulnerable to flooding from storms, even though they can be considered upland coastal habitat relative to nearby swamps and marshes. The National Wetland Inventory tends to map such forests as palustrine forested deciduous broad-leaved wetlands, although it regards "developed" natural levee areas cleared for agriculture and residential use as uplands (i.e., non-wetlands).

Live oak forests provide ecologically important coastal wildlife habitat in Louisiana as well as other GOMA coastal states. Live oak forests and other higher elevation coastal forests offer important coastal habitat to a variety of flora and fauna, including endangered species and migratory songbirds [2]. Louisiana coastal live oak forest types are considered rare and imperiled by the State of Louisiana and the Nature Conservancy [3]. Such forests have been identified by the Louisiana's Coastal Forest Conservation Initiative as a priority for land acquisition or conservation easements [4] and were originally proposed to the Coastal Impact Assistance Project as candidates for such purposes by the Nature Conservancy [5].

Unfortunately, Louisiana coastal live oak and other higher elevation coastal forest cover types are threatened by coastal subsidence, salt water intrusion, invasive plant species, agriculture, and urbanization. Much of the forecasted land loss is related to combined effects of sea-level rise and subsidence [6]. Elevation loss has occurred in coastal Louisiana at a rate of 1 foot per century [7], and some areas have experienced subsidence rates as high as 3 feet per century [8]. Since the prehistoric time prior to Columbus, natural levees in this region have been the land form of choice for human occupation [9]. Much of the least floodprone areas in New Orleans are in fact built upon natural levees [10]. In coastal Louisiana, subsidence and salt water intrusion has often caused coastal forest mortality to the point where only vestiges of former live oak forests remain (Fig. 2). Such areas may be suitable for coastal restoration if discretely identified. For example, subsided, degraded chenier ridges near Bayous Cochon and Moreau are currently being restored [11]. 


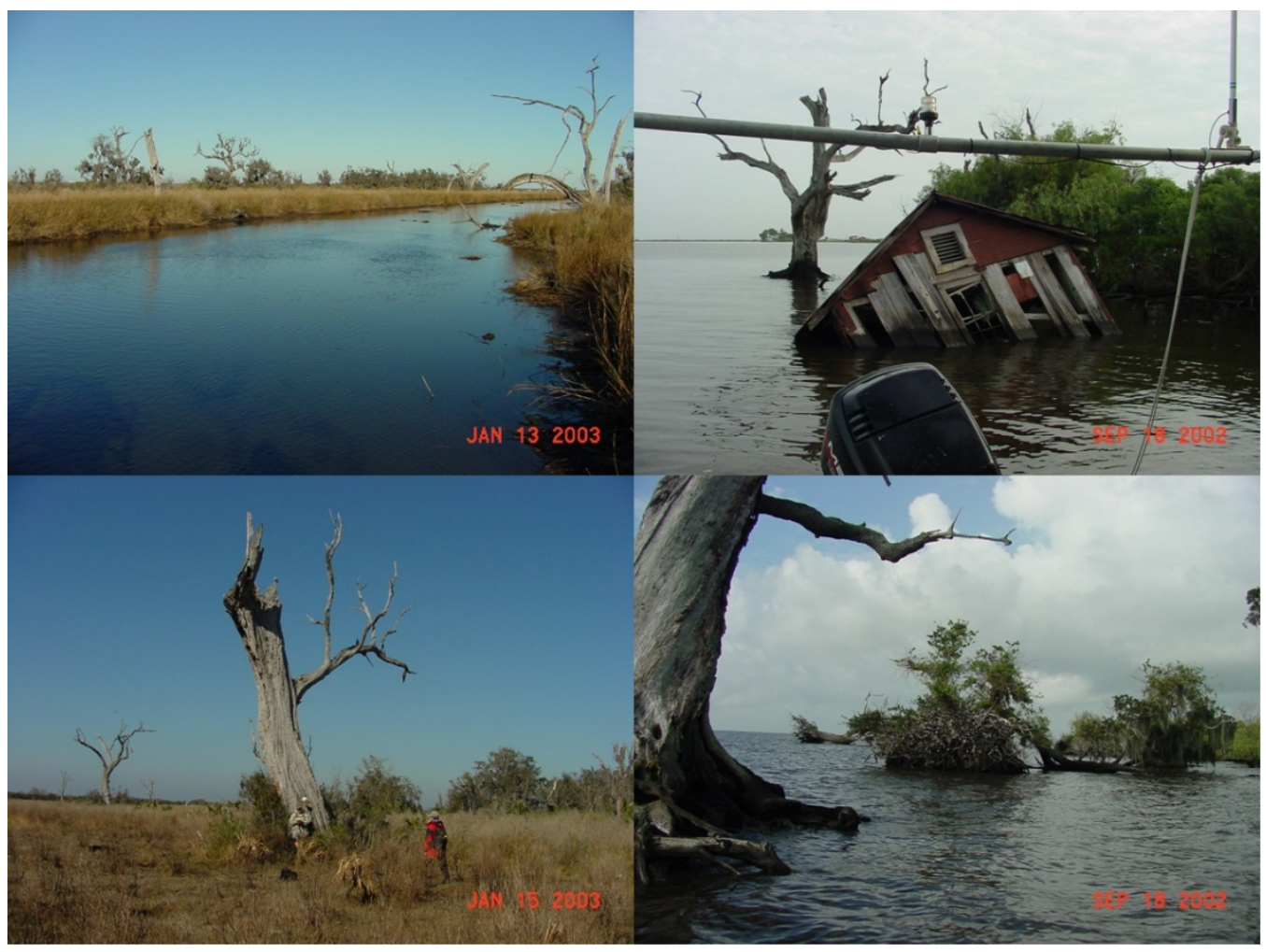

Fig. 2. Examples of subsiding, dead, or declining coastal live oak forests in Southeastern Louisiana.

\section{Relevant Previous Work on Remote Sensing of Forests}

A literature review did not show any publications that discussed use of NASA satellite data in deriving forest species cover type mapping products for the coastal forests along the Gulf of Mexico. However, it did find a study by [12] in which the authors reviewed published literature on the value of using multi-date Landsat data from multiple seasons to improve spectral data-based classification of subtle, hard-to-identify forested types. This study produced an impressive classification of wetland and upland forest cover types in the Roanoke River of North Carolina, where it was found that early and mid-spring data in this region was less favorable than summertime imagery for identifying targeted forest types. This study did not identify live oak forests, although its final classification did include an upland white oak-hickory category that was accurately classified compared to reference data [12].

Multispectral satellite remote sensing data has been used to map individual forest species, either as a predominant cover type or on a fractional abundance basis. As an alternative to mapping predominant land cover, [13] applied Landsat data and the commercial Sub-pixel Classifier software package to compute the fractional abundance of baldcypress and water tupelo on a perpixel basis using a study site in South Carolina. The latter technique offers potential for improved assessment of mixed baldcypress-water tupelo stands. Vegetation indices from satellite data, such as Normalized Difference Vegetation Index (NDVI), Normalized Difference Moisture Index (NDMI), and tasseled cap wetness (TCW) index, have also been useful for assessing forest harvest disturbance at the forest stand level of observation [14, 15, 16, 17, 18, 19]. Such indices have also been used on many occasions to assess forest defoliation from insects [20,21, 22] and from abiotic factors, such as hurricanes $[23,24,25]$ and wildfires [26].

\section{METHODS}

Several Landsat, ASTER, and MODIS satellite datasets were acquired, imported into ERDAS IMAGINE ${ }^{\circledR}$, and preprocessed into datasets suitable for computing classifications and change detection products. Preprocessing steps included computation of Normalized Difference Vegetation Index (NDVI) and Normalized Difference Moisture Index (NDMI) products for each date of acquired Landsat and ASTER data. For the multi-date classification, a 3-date data stack was computed using Landsat TM reflectance bands 3, 4, 5, and NDVI for each date. The three dates selected for this classification were May 1, 1987; October 8, 1987; and January 28, 1988. The single date classification was acquired on was January 28, 1988. 
Image classifications were performed to identify higher elevation coastal forests with and without live oak as a common forest stand component. This was done by employing a combination of satellite and airborne data products. Elevation data from 30- meter products were used to isolate coastal areas with 5 feet or less elevation. This definition enabled analysts to focus effort on areas where coastal high elevation forests in this region tend to occur. A higher spatial resolution elevation dataset from lidar data was used to refine identification of candidate sites for higher elevation coastal forests. A rule of 2.75 feet to 5 feet elevation was employed. Pre-existing coastal zone, conservation area, and geologic maps were considered in setting these elevation thresholds.

In parallel, image classifications were performed to identify type occurrence on the basis of spectral analyses of multi-date and single-date Landsat data. In general, there was too little coverage of ASTER data to use it as a primary data source, although a few quality scenes were available for supporting the Landsat-based analyses. A Landsat classification based on 3 dates from 3 seasons of data was performed based on ISODATA unsupervised classification with ERDAS IMAGINE software. The initial classification contained 20 clusters, based on a .995 convergence threshold and 100 maximum iterations. This initial classification contained one cluster class that included bottomland hardwood forests that also contain live oak concentrations. The raw data for this cluster was then isolated via masking and then reclassified using a cluster busting technique described by [27]. The elevation mask was then applied to further reduce commission errors. The resulting product was a map of the higher elevation coastal forest areas.

To identify live oak forests within this broadly defined type, an additional classification strategy was employed in which singledate Landsat data were used to predict locations and extent of live oak forest within the study area. This approach employed Landsat data from January. At this time of year, live oak forest in this region tends to retain its canopy, whereas its common associates tend to senesce and lose their leaves. Later in the winter, live oak forests also senesce and lose leaves, although generally not all of their leaves.

Live oak forests were classified on the January 28, 1987, scene via ISODATA unsupervised classification. An initial classification was computed with 30 cluster classes. Then, cluster classes with highly green forest canopies in the study area were then used as a mask to isolate raw data for reclassification. The cluster classes associated with live oak forest were then identified to produce the final classification for this cover type.

Field surveys were conducted in multiple parishes via automobile and boat. Surveyed habitats included coastal forests on natural levees, cheniers, and beach ridges. Surveys were performed to check preliminary products. At each surveyed location, GPS points, digital photography, and notes describing forest species composition and condition were collected. These field checks were done to assess and refine preliminary classification and change detection products.

Change detection products were produced from Landsat and MODIS datasets. These products were constructed to visualize change across the Landsat TM and MODIS eras. Separate Landsat products were generated using 3 dates (years of same season data) from NDVI and NDMI. Separate 3-date products were generated for the following date triplicates: 1) 3 dates of spring data - April 6, 1984; April 2, 1994; and April 6, 2007; and 2) 3 dates of fall data (October 8, 1987; October 3, 1997; and September 26 , 2006). RGB color composites of 3-date NDVI and 3-date NDMI stacks were assessed by viewing screen displays to identify changes in the higher elevation coastal forests previously identified via classification. The 3-date NDVI and NDMI products were then subjected to image classification to map and assess changes within higher elevation coastal forests.

\section{RESULTS}

The moderate- and high-resolution elevation data enabled the coastal region of interest to be more clearly defined. Moderate resolution 30-meter bare earth elevation data from the State of Louisiana were used to generally define the coastal plain as those areas of 5 feet or less. This elevation zone contained the majority of candidate sites containing coastal forest. Within these areas, as available, higher resolution, bare earth, lidar elevation data aided the separation between higher and lower elevation sites. In doing so, higher elevation sites were defined as those higher than or equal to 2.75 feet. The moderate-resolution elevation product defined elevations in terms of full foot increments.

In conjunction with the elevation data, the 3-date classification product was applied to identify higher elevation coastal forests (Fig. 3). These breakouts were not perfect (i.e., some commission and omission errors occurred), although they were still highly useful given that these are new, previously unavailable products. For the 3-date, 3-seasons classification, cloud cover was an issue in scene selection. One of the scenes had noteworthy cloud cover, although the vast majority was in coastal Mississippi or elsewhere away from areas containing coastal forest. Suitable scenes were selected over a 2-year window that was early in the Landsat TM era. The intent was to employ the classification product as a baseline for use in assessing the context of forest change detections. Instead of trying to select data for 3 seasons in the same year or two, it may be a better strategy to select the most cloud free-datasets for 3 seasons over a 3-year time frame. 
Selection of suitable spring time data can be further complicated by insect defoliation of forests, although this did not seem to be a factor when mapping higher elevation coastal forests. It can be a factor in regard to classifications of swamp forests due to water tupelo defoliation from forest tent caterpillar and cypress defoliation from baldcypress leaf roller. Ideally, the 3-date, 3-season triplicate should be as close in time as possible (start-year to end-year) to minimize land cover change between the selected dates.

The single-date classifications yielded useful indications of live oak forest among lower elevation swamp and marsh areas (Fig. 4). The use of January data shows the power of employing cover type phenology in selection of datasets for type-specific classification. During this time of year, live oak forests generally retain their vegetation, although other co-associate tree species in this region tend to be leaf off. At the Landsat scale, it should be noted that there was not much acreage of live oak forest identified, although this is not surprising since the type is considered rare and imperiled. This technique needs to be used with caution, as it may not be effective in areas with co-occurring evergreen conifer and hardwood species. However, the technique is conditionally useful for mapping this comparatively rare coastal forest cover type. It seems to work for coastal plain areas that are largely marsh and swamp forest-dominated.

The change detection products from Landsat and MODIS data showed disturbance from hurricanes, timber harvests, and conversion to urban land use. It appears that Hurricane Katrina caused major damage to natural levee forests in St. Bernard and St Tammany Parishes of Louisiana, as well as Hancock County of Mississippi (Fig. 5).

\section{CONCLUSIONS AND FUTURE WORK}

The results of the case study indicated the feasibility of producing effective maps of coastal higher elevation forests within the study area. In particular, it was determined that useful classifications of general and type-specific forest classifications could be computed with unsupervised techniques when appropriate dates of imagery were used as an input. These results, while promising, are not validated at the time of this writing. However, these classification products are now in a form where a quantitative validation could be performed. 


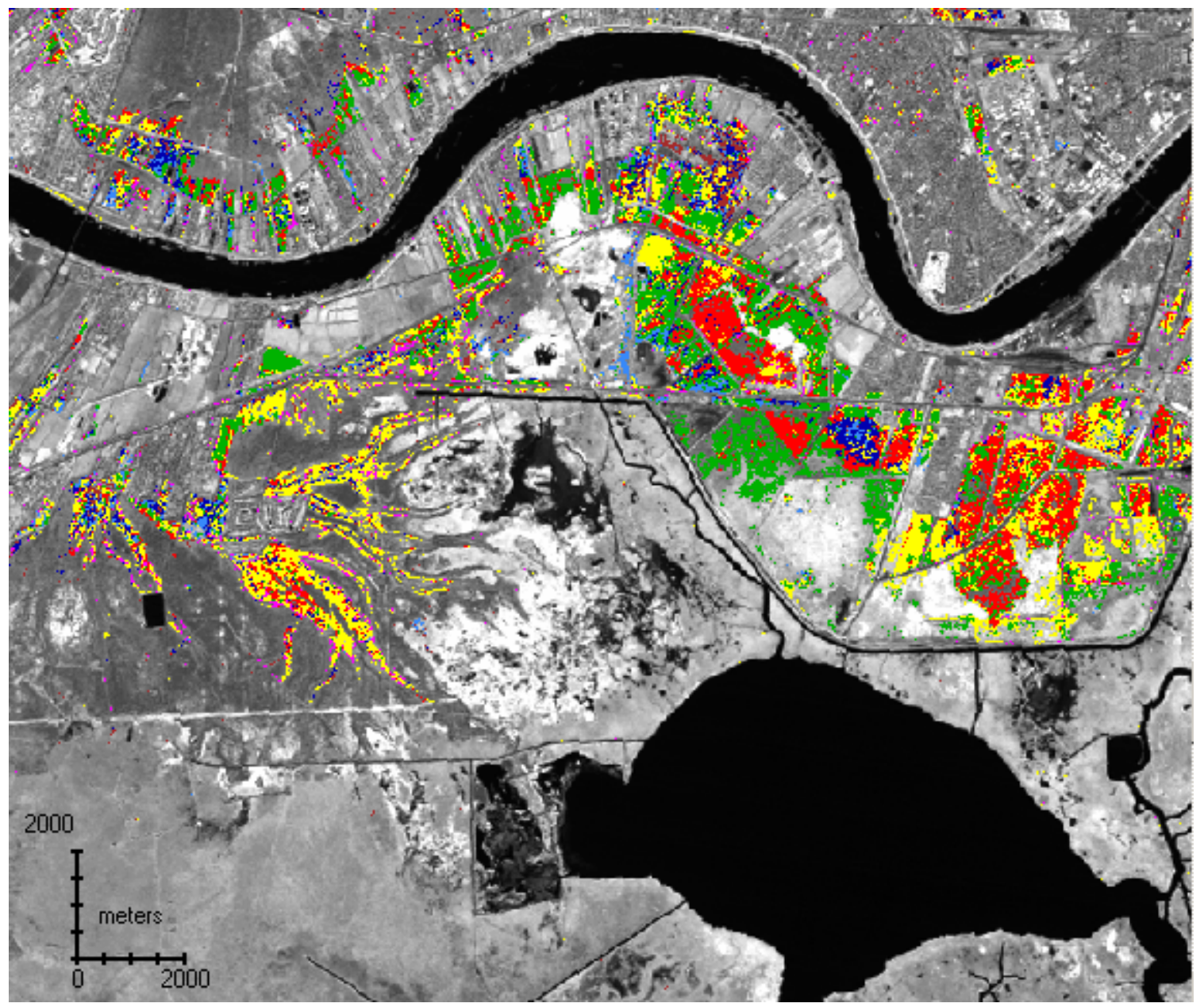

Fig 3. Classification of high elevation coastal forest draped over Landsat near infrared image. The colors denote cluster classes that were positively associated with higher elevation coastal landforms, such as natural levees. The product shown here was computed from a three date, three season classification, based on data from May 1, 1987; October 8, 1987; and January 28, 1988. The area shown includes Luling, Louisiana. 


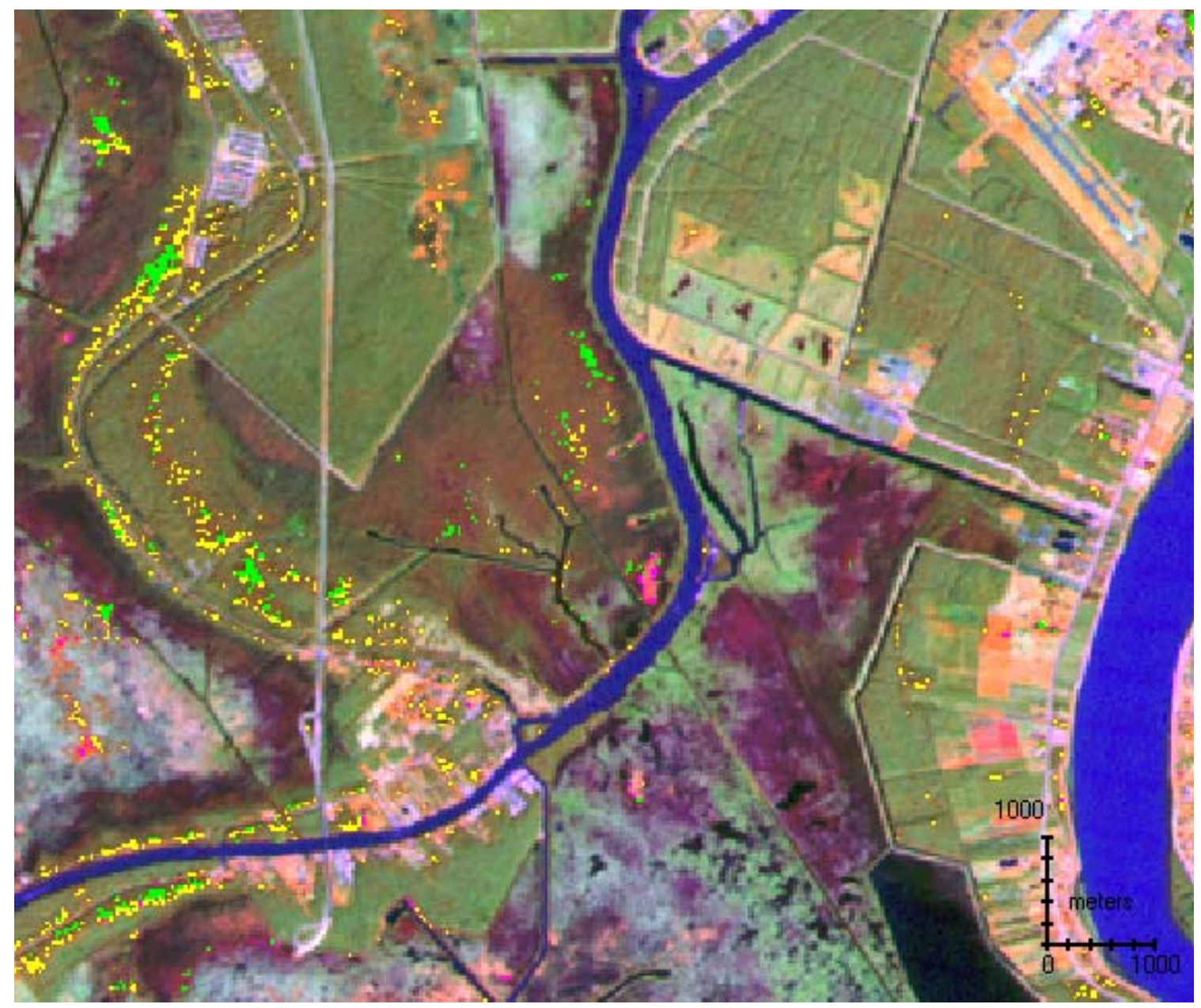

Fig 4. Classification of higher elevation coastal forested areas that include live oak forest (areas coastal live oak forests are shown in green and yellow tones). The green tone includes contiguous live oak forests, whereas the yellow tone depicts mixed hardwood forests with live oak trees. The classification shown here is draped on a Landsat false color composite image originally acquired January 28,1988 . The latter was used to compute the classification in the foreground. The area shown is south of Marrero, Louisiana, near Jean Lafitte. 


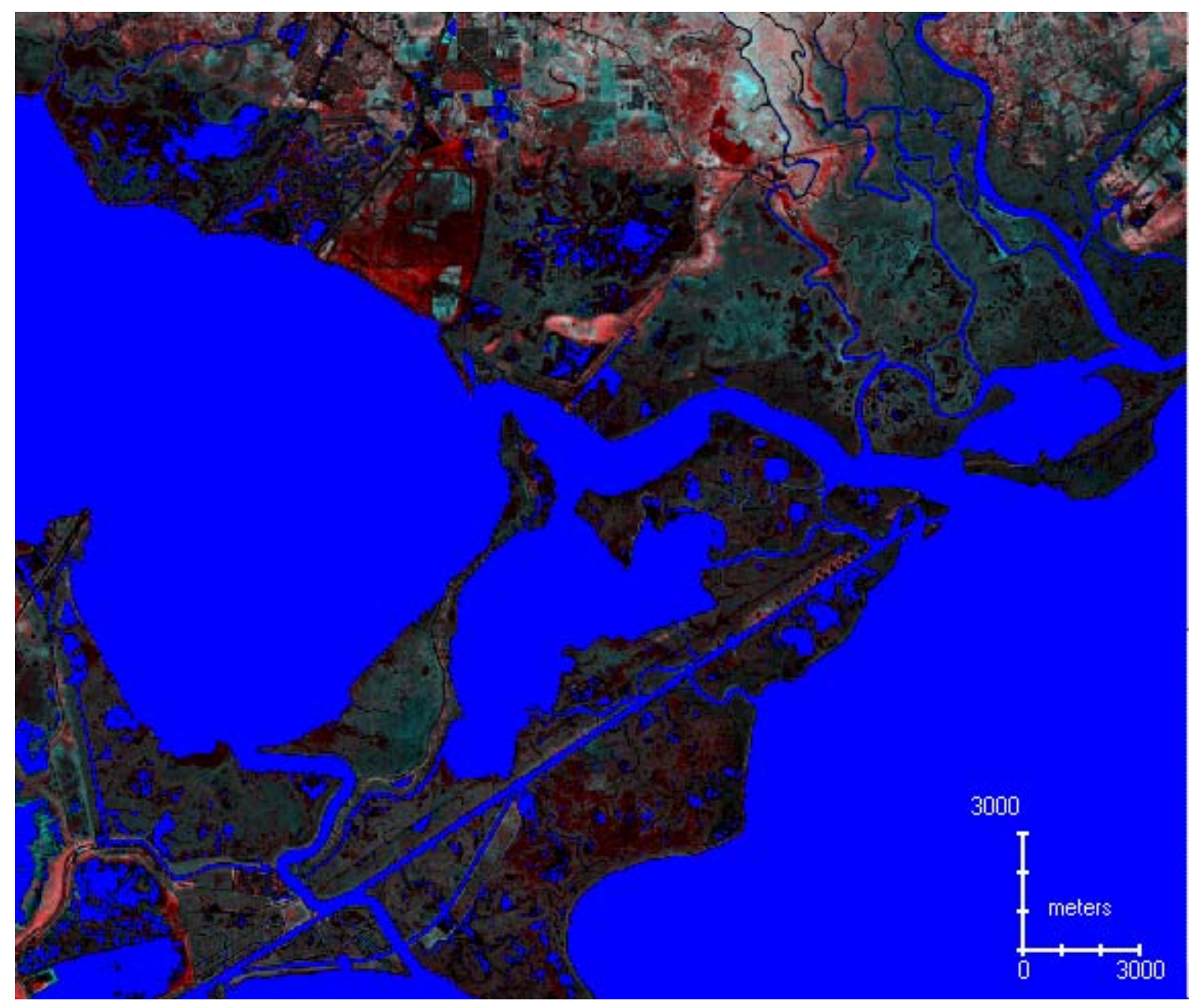

Fig 5. View of Landsat-based change detection visualization product that includes NDVI from April 2, 1994 in the red color gun and April 6, 2007 NDVI in the blue and green color guns. The resulting color composite shows areas with NDVI drops in red tones. The deep red tones within the identified higher elevation coastal forests are indicative of damage that occurred from Hurricane Katrina. Subsidence may also be a factor in the Bayou Sauvage area (lower left). Forested areas without NDVI loss appear as a light gray tone, whereas marshes with a constant NDVI in this image have a dark gray tone. The water component of the image has been removed and replaced with a blue color.

The case study results also provided visual evidence that effective change detection products could be computed for higher elevation coastal forests using Landsat for stand-level observations and MODIS data for regional assessments of forest change due to disturbance. The Landsat change visualization products showed disturbance from hurricanes, timber harvests, and conversion to urban land use. From the Landsat products, it appears that Hurricane Katrina caused major damage to natural levee forests in St. Bernard and St Tammany Parishes of Louisiana, as well as in Hancock County of Mississippi. The MODIS data also showed some promise for assessing phenology of coastal forest cover types. Phenology is an important consideration when developing strategies for classifying coastal forest cover types of interest to the coastal forest management, conservation, and restoration community.

Additional work is needed to complete this project as originally intended. In particular, quantitative product validation and product evaluations by projected end-users are needed. In addition, there was insufficient time to try more advanced classification techniques that compute the fractional abundance of forest canopy cover due to a particular targeted overstory species, such as live oak. Nonetheless, the project further demonstrated the potential of NASA data for aiding coastal forest monitoring in regard to NGOM coastal restoration and conservation needs. Fortunately, a follow-on project has been funded through the NASA ROSES A.28 solicitation of 2008. This new project will apply NASA-supported satellite data further to develop, validate, and distribute coastal forest monitoring information products to interested NGOM State and Federal government agency end-users. 


\section{ACKNOWLEDGMENT}

Participation in this research by Science Systems and Applications, Inc., was supported by NASA at the John C. Stennis Space Center, Mississippi, under Task Order NNS04AB54T.

\section{REFERENCES}

[1] Penfound, W. T., and E.S. Hathaway, 1938. Plant communities in the marshlands of southeastern Louisiana. Ecological Monographs 8(1): 3-56.

[2] Barrow, W.C. Jr., B. Fontenot, M.H. Barrow, R. DeMay, and D. Muth, 2006. Vanishing Before Our Eyes: Louisiana Cheniere Woods and the Birds that Depend on them. Barataria-Terrebonne National Estuary Program, 25 p.

[3] Lester, G.D., S.G. Sorensen, P.L Faulkner, C.S. Reid, and I.E. Maxit, 2005. Louisiana Comprehensive Wildlife Conservation Strategy. Baton Rouge, Louisiana Department of Wildlife and Fisheries, 455 p.

[4] LDNR [Louisiana Department of Natural Resources], 2007. Louisiana Coastal Impact Assistance Plan. Louisiana Department of Natural Resources, Baton Rouge, LA, 285 p.

[5] TNC [The Nature Conservancy], 2006. Conservation of Coastal Forests in Louisiana. Proposal submitted to Coastal Impact Assistance Program (CIAP), May 22, 2006, 6 p.

[6] Williams, K., Z.S. Pinzon, R.P. Stumpf, and E.A. Raabe, 1999. Sea Level Rise and Coastal Forests. USGS Open File Report 99-441, 127 p.

[7] Chambers, J.L., W.H. Conner, J.W. Day, S.P. Faulkner, E.S. Gardiner, M.S. Hughes, R.F. Keim, S.L. King, K.W. McLeod, C.A. Miller, J.A. Nyman, and G.P. Shaffer, 2005. Conservation, Protection and Utilization of Louisiana's Coastal Wetland Forests. Final Report to the Governor of Louisiana from the Coastal Wetland Forest Conservation and Use Science Working Group (special contributions from Aust, W.M., Goyer, R.A., Lenhard, G.J., Souther-Effler, R.F., Rutherford, D.A., and Kelso, W.E.). 121 p.

[8] LCWCRTF [Louisiana Coastal Wetlands Conservation and Restoration Task Force], 1998. Coast 2050: Toward a Sustainable Coastal Louisiana. Louisiana Department of Natural Resources, Baton Rouge, LA, 161 p.

[9] Kidder, T.R., 1998. The rat that ate Louisiana: Aspects of historical ecology in the Mississippi River Delta. In Advances in Historical Ecology, edited by W. Balée, pp. 141-168. Columbia University Press, New York.

[10] Saucier, R.T., and J.O. Snowden, 1995. Engineering geology of the New Orleans area. Pp. 131-154 in C. J. John and W. J. Autin, eds., Guidebook of Excursions, in conjunction with the annual meeting of the Geological Society of America, New Orleans, LA, November 6-9, 1995. Boulder, Colo.: Geological Society of America.

[11] Fine, G., and S. Edwards, 2005. Maritime Forest Habitat Restoration and Enhancement. USDA NRCS report, Alexandria, LA, August 25, 2005, 8 pp.

[12] Townsend, P.A., and S.J. Walsh, 2001. Remote sensing of forested wetlands: Application of multitemporal and multispectral satellite imagery to determine plant community composition and structure in southeastern USA. Plant Ecology 157:129-149.

[13] Huguenin, R.L., M.A. Karaska, D. Van Blaricom, and J.R. Jensen. 1997. Subpixel classification of bald cypress and tupelo gum trees in Thematic Mapper imagery. Photogrammetric Engineering and Remote Sensing 63 (6): 717-725.

[14] Sader, S.A., and J.C. Winne, 1992. RGB-NDVI color composites for visualizing forest change dynamics. International Journal of Remote Sensing 13 (16): 3055-3067.

[15] Franklin, S.E., M.B. Lavigne, M.A. Wulder, and G.B. Stenhouse, 2002. Change detection and landscape structure mapping using remote sensing. The Forestry Chronicle 78 (5): 618-625.

[16] Wilson, E.H., and S.A. Sader, 2002. Detection of forest harvest type using multiple dates of Landsat TM imagery. Remote Sensing of Environment 80: 385396.

[17] Jin, S., and S.A. Sader, 2005. Comparison of time-series tasseled cap wetness and the normalized difference moisture index in detecting forest disturbances. Remote Sensing of Environment 94 (3): 364-372.

[18] Hayes, D.J., and W.B. Cohen, 2007. Spatial, spectral and temporal patterns of tropical forest cover change as observed with multiple scales of optical satellite data. Remote Sensing of Environment 106 (1): 1-16.

[19] Hayes, D.J., W. Cohen, S.A. Sader, and D.E, Irwin. 2008. Estimating proportional change in forest cover as a continuous variable from multi-year MODIS data. Remote Sensing of Environment 112:735-749.

[20] Vogelmann, J.E., 1990. Comparison between two vegetation indices for measuring different types of forest damage in the Northeastern United States. International Journal of Remote Sensing 11:2281-2297.

[21] Williams, D.L., and R.F. Nelson, 1986. Use of remotely sensed data for assessing forest stand conditions in the Eastern United States. IEEE Transactions on Geoscience and Remote Sensing GE-24: 130-138.

[22] de Beurs, K.M., Townsend, P.A., 2008. Estimating the effect of gypsy moth defoliation using MODIS. Remote Sensing of Environment, 112:3983-3990

[23] Ramsey, E.W. III, D.K. Chappell, and D. Baldwin, 1997. AVHRR imagery used to identify Hurricane Andrew damage in a forested wetland of Louisiana. Photogrammetric Engineering and Remote Sensing 63 (3): 293-297.

[24] Ramsey, E.W. III, D.K. Chappell, D.M. Jacobs, S.K. Sapkota, and D.G. Baldwin, 1998. Resource management of forested wetlands: Hurricane impact and recovery mapped by combining Landsat TM and NOAA AVHRR data. Photogrammetric Engineering and Remote Sensing 64 (7): $733-738$.

[25] Ramsey, E.W. III, M.E. Hodgson, S.K. Sapkota, and G.A. Nelson, 2001. Forest impact estimated with NOAA AVHRR and Landsat TM data related to an empirical hurricane wind-field distribution. Remote Sensing of Environment 77 (3): 279-292.

[26] van Leeuwen, W.J.D., 2008. Monitoring the Effects of Forest Restoration Treatments on Post-Fire Vegetation Recovery with MODIS Multitemporal Data. Sensors, 8, 2017-2042.

[27] Jensen, J.R., Ramsey, E.W., Mackey, H.E., Christensen, E.J., and Sharitz, R.R. 1987. Inland Wetland Change Detection Using Aircraft MSS Data. Photogrammetric Engineering and Remote Sensing 53(5): 521-529. 
- Presented by Joe Spruce, SSAI

- Co-authors: James Smoot and William Graham

- Oceans '09 Conference, October 29, 2009 


\section{Project Background}

- This presentation discusses a project on the use of NASA data for aiding coastal forest restoration and conservation along the Northern Gulf of Mexico

- This region includes extensive, diverse coastal forests that provide multiple ecological services and benefits

- Unfortunately, these low-lying forests are subject to many abiotic and biotic threats

- NASA-supported data (e.g., Landsat, ASTER, and MODIS) may help to identify and assess vulnerable coastal forests

- Such data may help yield improved maps that can aid coastal forest land acquisition and conservation easements

- Especially for swamp and bottomland hardwood forests 


\section{Louisiana Coastal Cover Types Compared to Landforms}

Foot to sub-foot differences in elevation can occur between these cover types

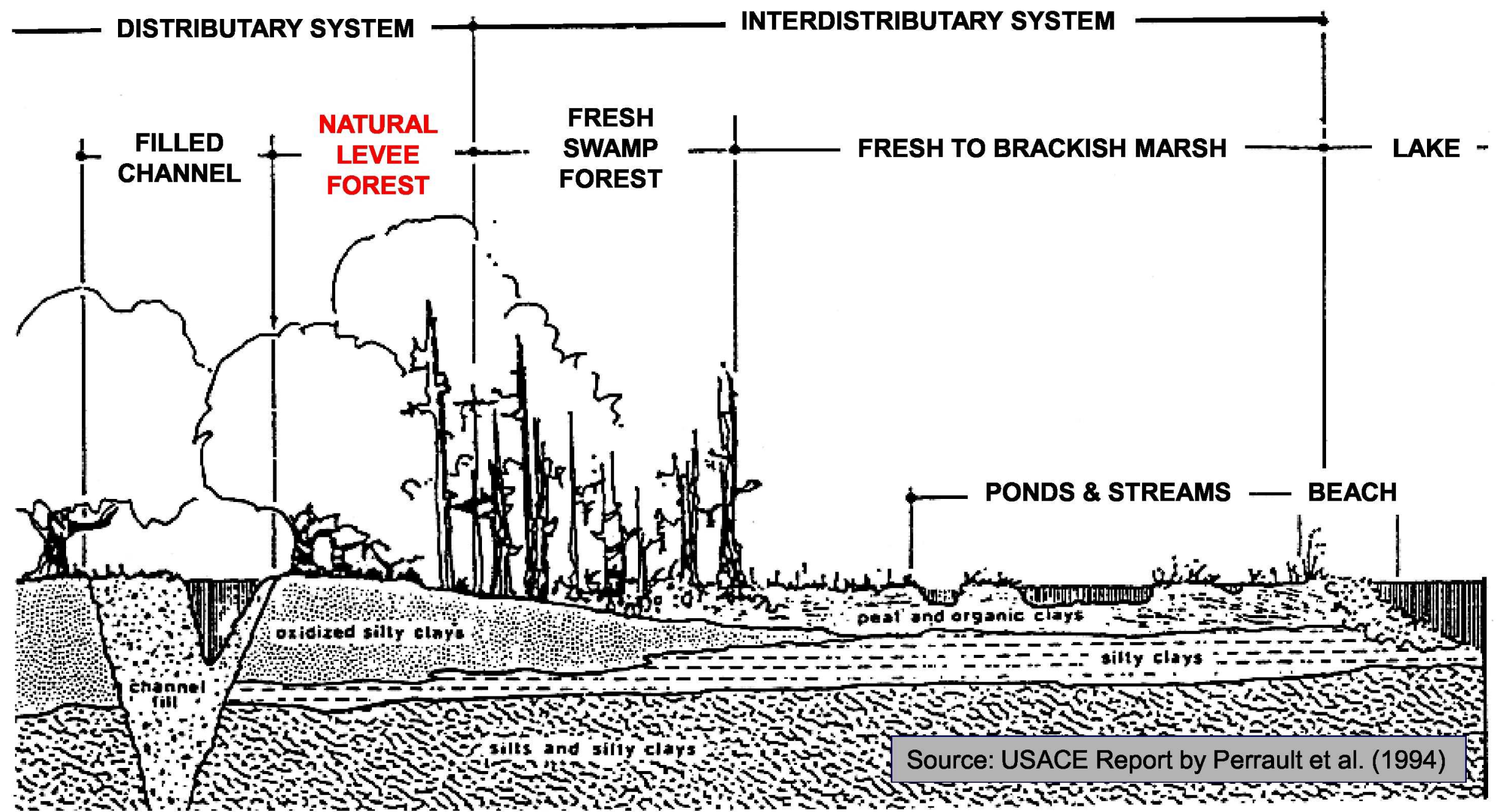




\section{Coastal Forest Loss and Decline}

Examples of Subsided, Declining Natural Levee Forests in Southeastern Louisiana

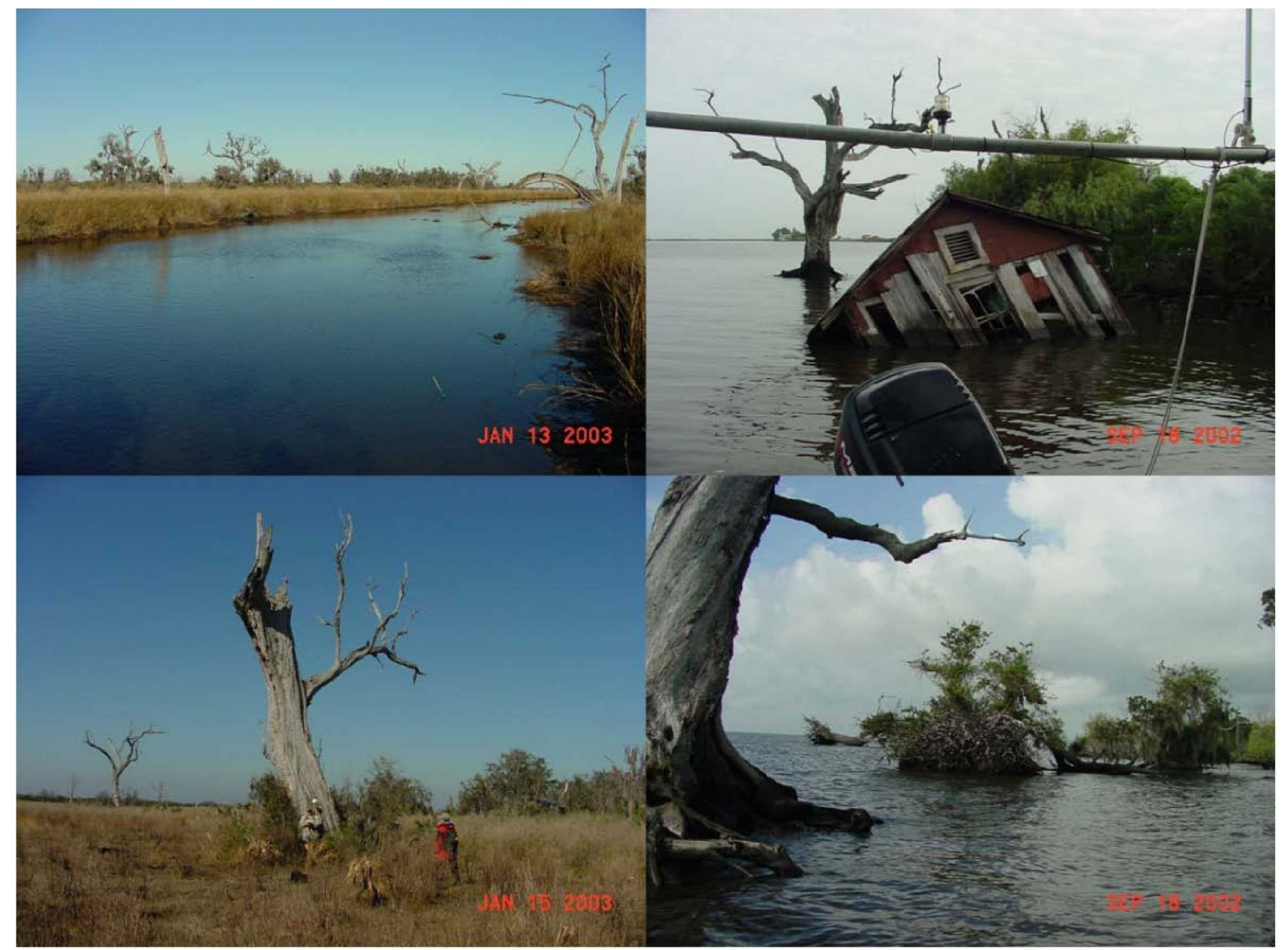




\section{Phases of Project Development}

- Phase 1 - initial preliminary study on technical feasibility of using NASA data for aiding cypress forest monitoring

- Phase 2 - submitted proposal "Use of NASA satellite data to improve coastal cypress forest management" for NASA Gulf of Mexico solicitation

- Phase $3-2^{\text {nd }}$ preliminary study on use of NASA data for monitoring coastal higher elevation forests

- Phase 4 - implement new NASA-funded follow-on project

(Note - this presentation focuses on Phase 3) 


\section{Objectives}

1. Assess potential of NASA-supported data for revising maps of higher elevation coastal forests occurring on natural levees, cheniers, and barrier islands

2. Examine potential of NASA data for identifying changes in these higher elevation coastal forests 


\section{Study Area Location}

Stennis Space Center

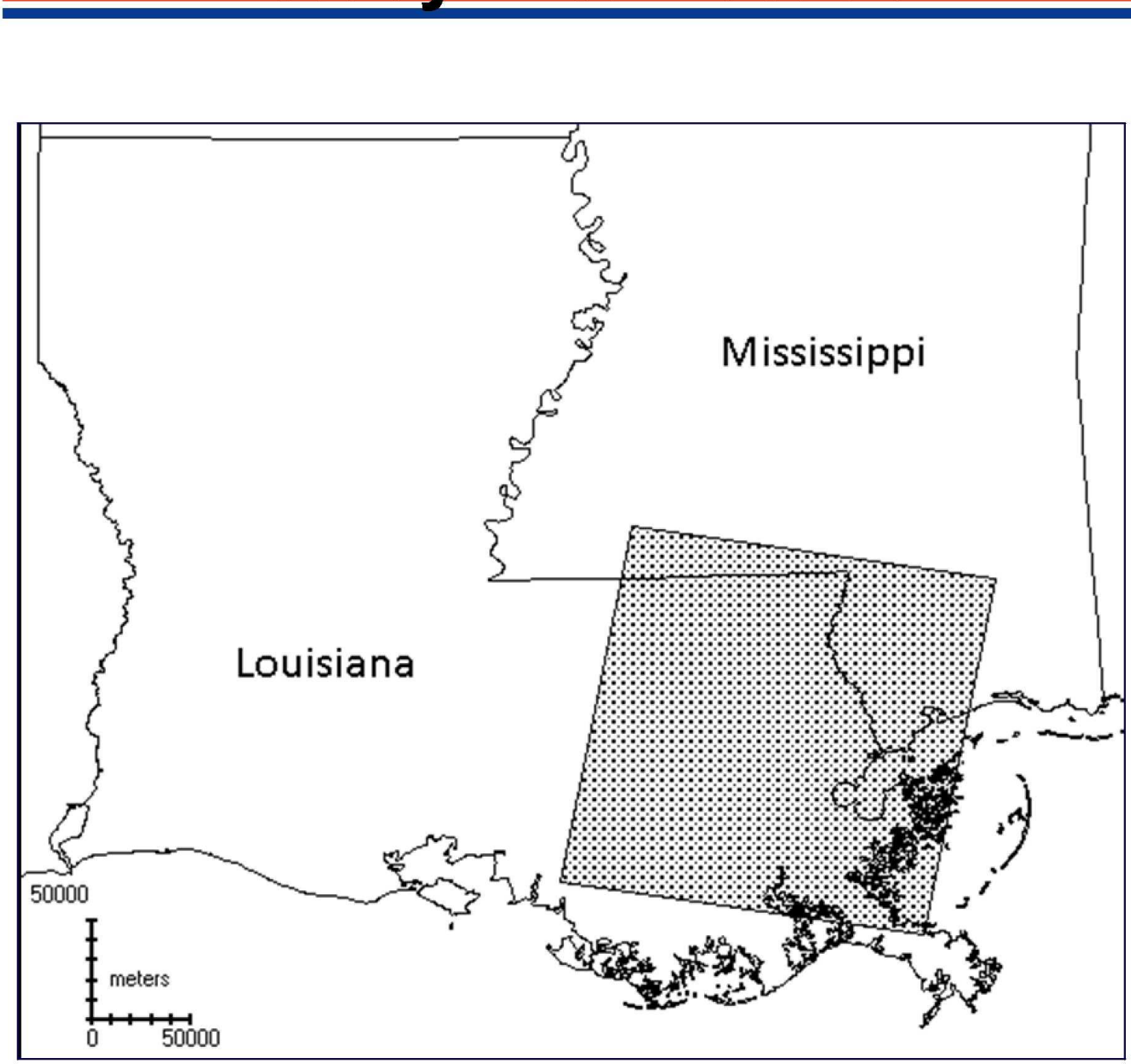

Main Location Coastal Plain of SE Louisiana (Within Path 22 Row 39 of

Landsat WRS)

Secondary Location Chenier Plains of SW Louisiana 


\section{Methods}

- Data Acquisition - Landsat, ASTER, MODIS data in conjunction with aerial elevation and ground reference data

- Data Preprocessing - Standard preparations for satellite data, such as scaling data to reflectance, computing vegetation index products, computing multichannel, multidate data stacks as precursor to image classification

- Image Classification - Computation of forest cover type and change detection products, based on unsupervised classification of single-date and multi-date time series data

- Product Validation - Qualitative and quantitative validation of classification products compared to higher spatial resolution reference data, including field data 


\section{Initial Multi-Date Landsat Classification of Higher Elevation Coastal Forests}

Stennis Space Center

Classification Result is Draped on Landsat NIR Image

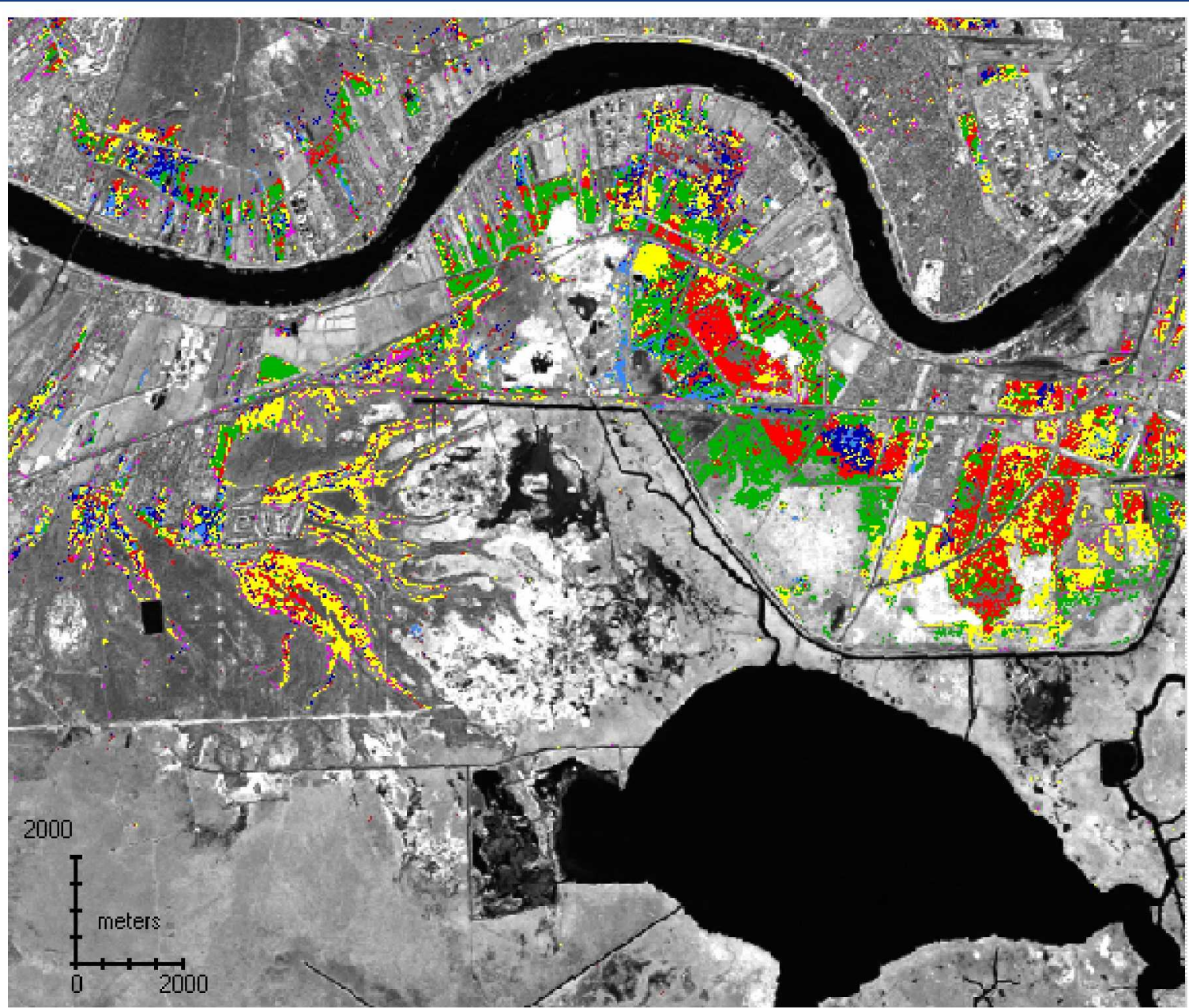

Location Near Luling, Louisiana

Preliminary classification of higher elevation coastal forest, based on Landsat TM data from May 1, 1987; October 8, 1987; and January 28, 1988. The colored classes show potential higher elevation coastal forest, compared to available elevation and land cover data. However, most of these classes (e.g., red and green) include higher elevation swamps. 


\section{October 1987 Landsat View of Multi- Date Classification Area}

Stennis Space Center

Bottomland Hardwoods Tend to Keep Foliage Longer into Fall and Early Winter

TupeloDominated Swamp Forests are Defoliated By Mid-Fall

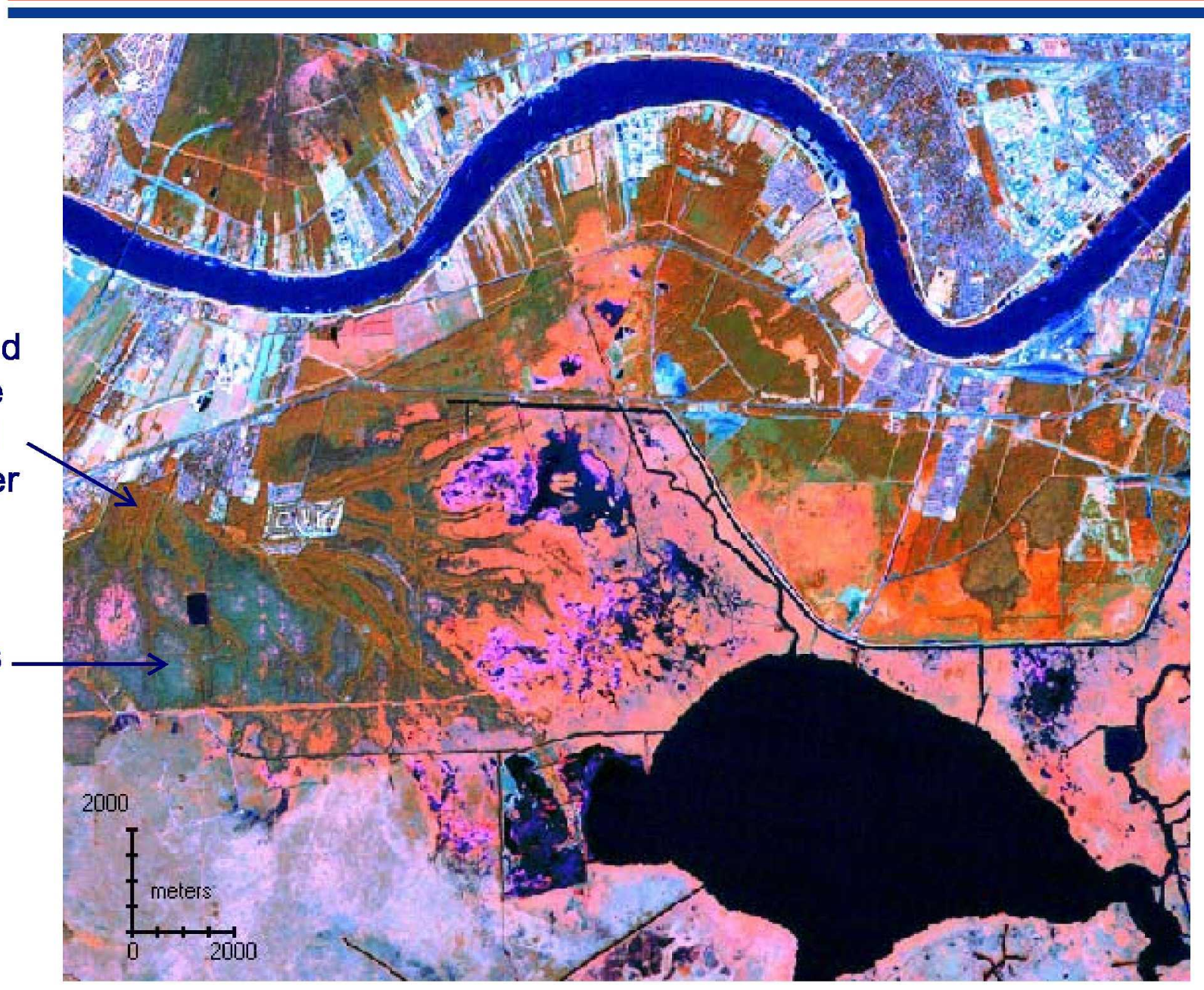

Location Near Luling, Louisiana

Landsat RGB shown above is from October 8,1987 . The classes shown in previous image do not occur in completely senesced, lower elevation swamp forests. 


\section{Digital Elevation Model from 5-Meter Lidar Data}

Stennis Space Center

Most Classes in Previous Product Exclude the Lower Elevation Swamps and Marsh

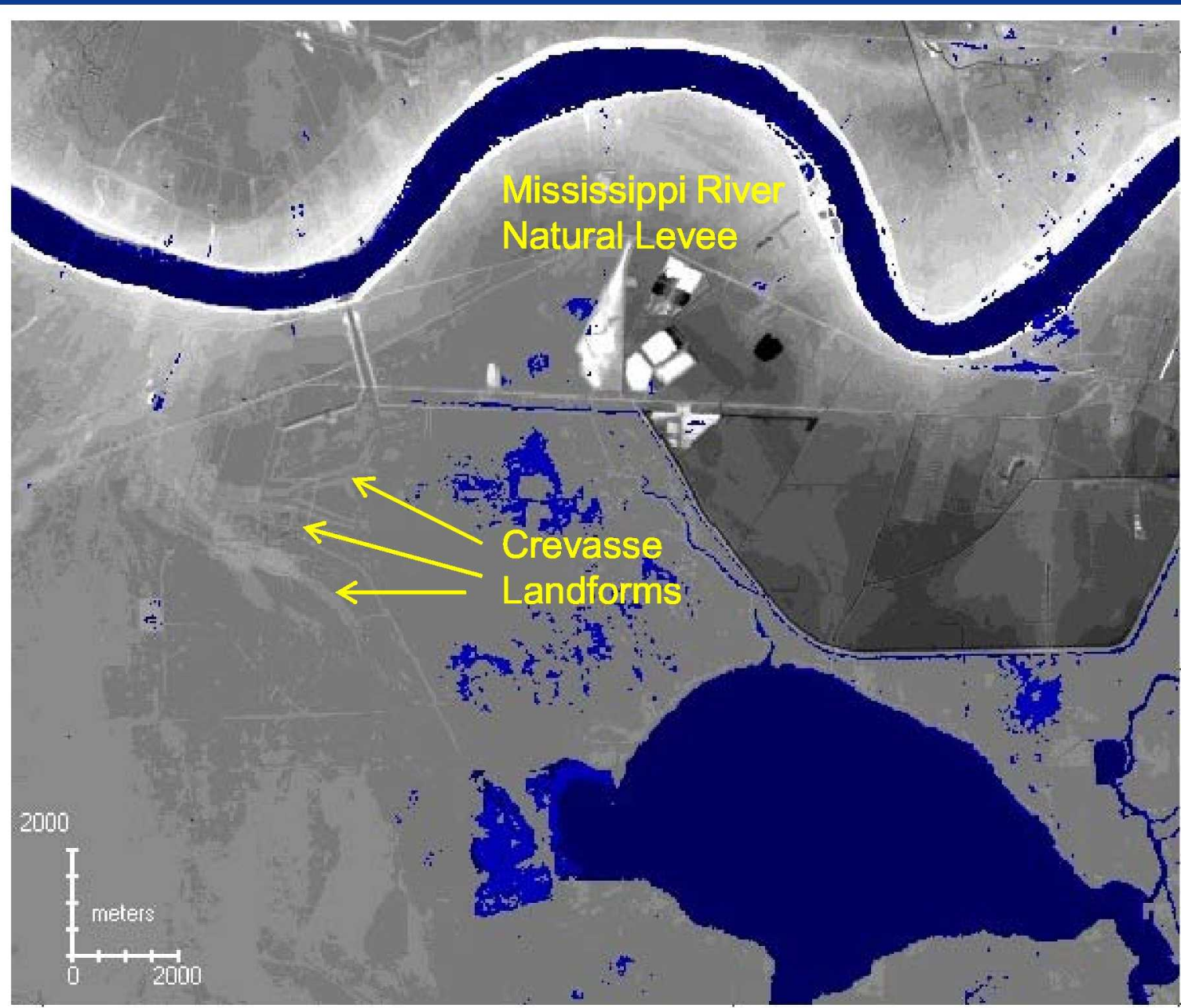

Location Near Luling, Louisiana

The product above was used in part to assess the preceding product. The classification mostly showed forested areas on the flanks of this natural levee and on the higher portions of a crevasse ridge. 


\section{Single-Date Landsat Classification of Potential Live Oak Forests}

Classification Result is Draped on Landsat RGB

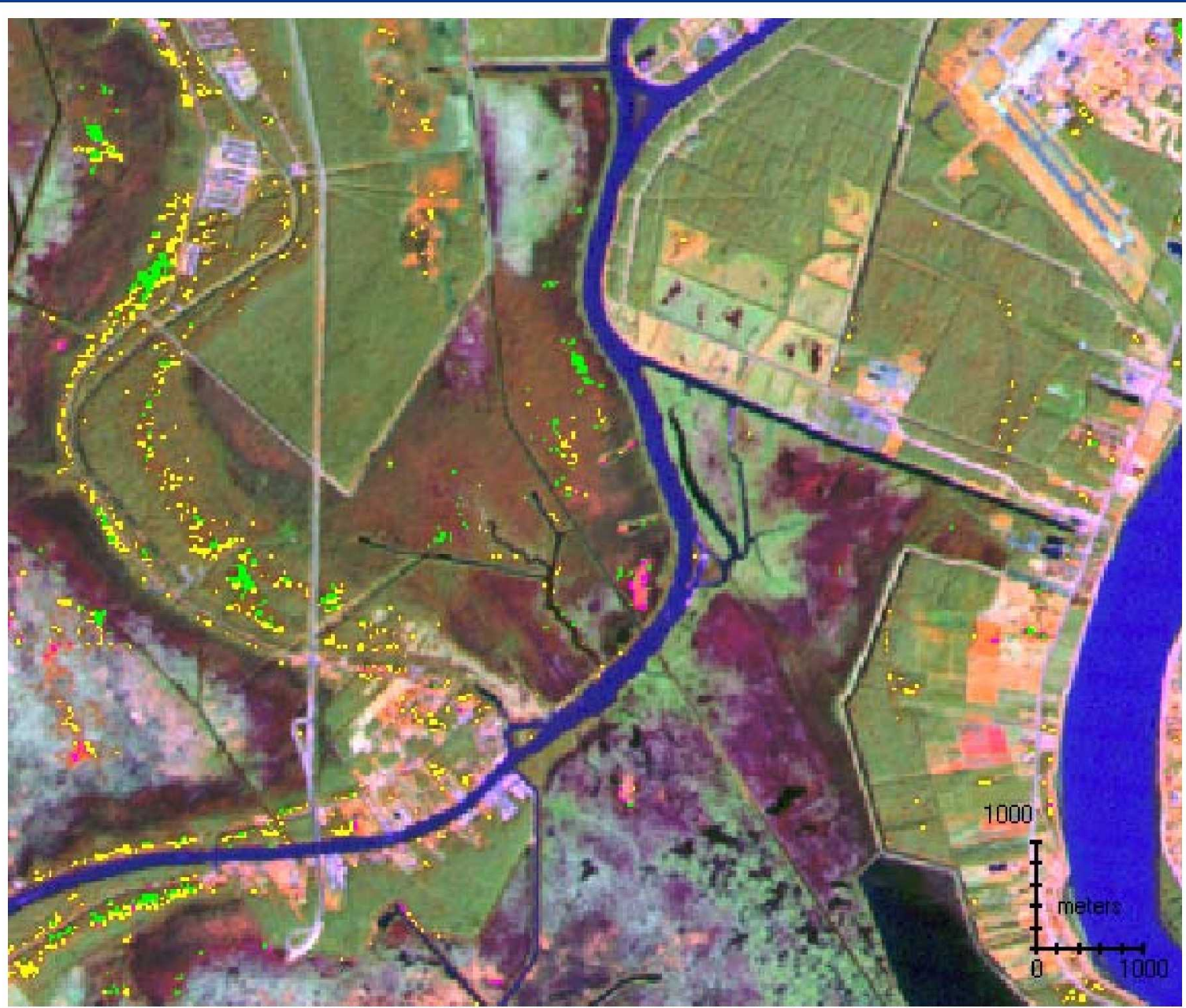

Location Near Marrero, Louisiana

Classification of higher elevation coastal forests that include live oak forest, based on Landsat TM data from January 28, 1988. Green and yellow tones depict green canopy forests growing on natural levees. The green tone is more likely to include contiguous live oak forests, whereas the yellow tone shows mixed bottomland hardwoods. 


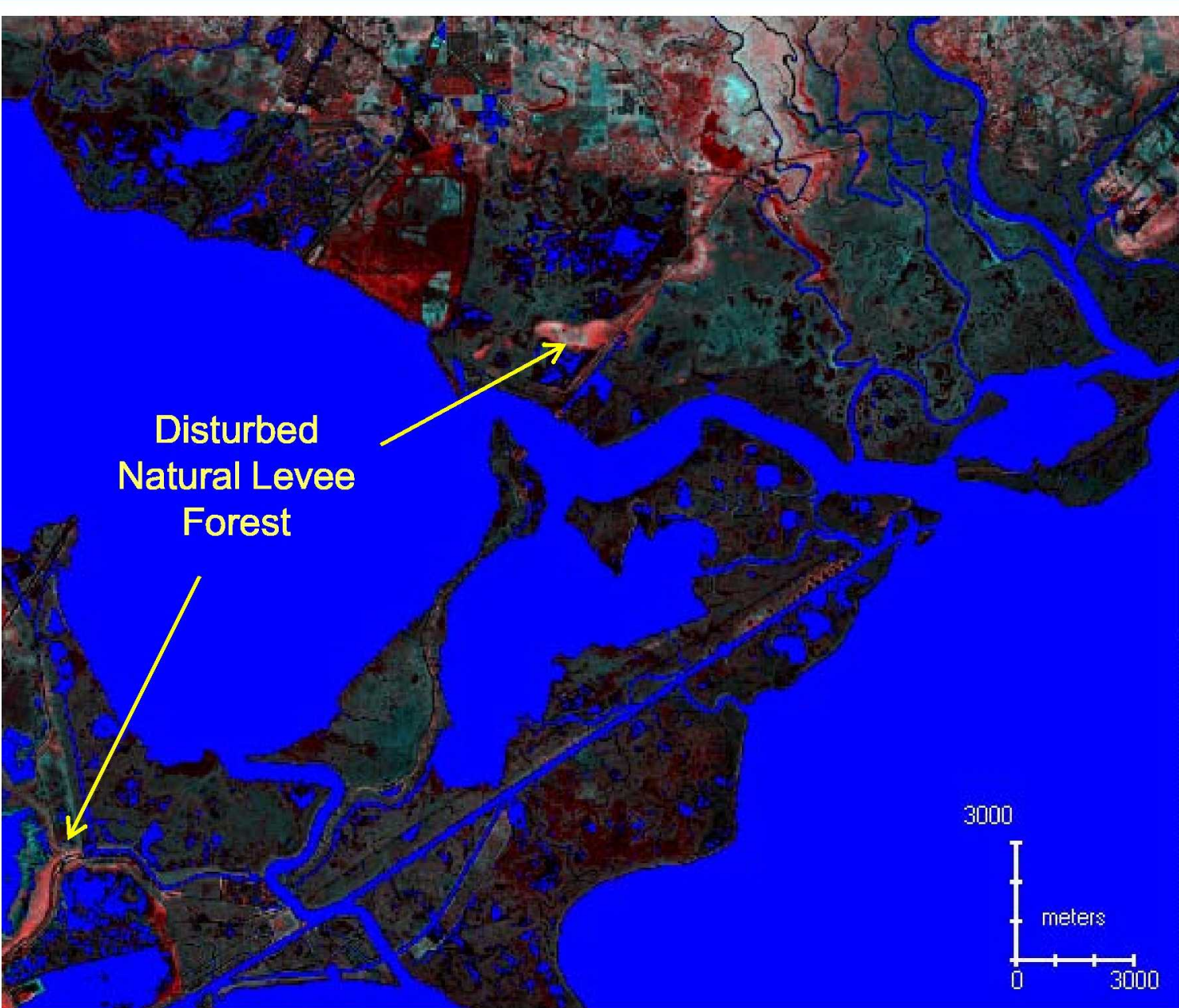

Location - Border of St. Tammany and St. Bernard Parishes

Two-date color composite of Landsat NDVI from April 2, 1994, in the red color gun and April 6, $2007 \mathrm{NDVI}$ in the blue and green color guns. Healthy forests are in light gray, whereas marshes are shown as dark gray tones. Red tones indicate disturbed vegetation (e.g., forests) with drops in $\mathrm{NDVI}$, often related to Hurricane Katrina damage. Water areas are in blue. 


\section{Initial Findings}

- Both multi-date and single-date Landsat classifications showed some potential for depicting locations of higher elevation coastal forest

- Single-date products from mid-winter showed the best potential for identifying natural levee forests containing live oak

- Multi-date products (3 seasons of same year) showed some potential for classifying higher elevation coastal forests

- Multi-date Landsat products were useful for viewing coastal forest disturbances

- These preliminary results were mixed, yet encouraging, given the availability of quality Landsat and lidar data

- However, more field validation and product development is clearly needed 


\section{Potential Beneficiaries of Project}

\section{Groups Involved with Coastal Forest Restoration}

- Federal Agencies

- U.S. Army Corps of Engineers

- U.S. Geological Survey

- U.S. Mineral Management Service

- U.S. Environmental Protection Agency

- U.S. Forest Service

- State Agencies

- LA Department of Natural Resources

- LA Department of Environmental Quality

- Other Relevant Organizations

- Barataria Terrebonne National Estuary Program

- The Nature Conservancy

- Louisiana State University 


\section{Future Work}

- Work with collaborators to implement the follow-on NASAfunded project regarding use of NASA data for aiding coastal cypress forest management

- 2-year project in collaboration with USACE, USGS, LDNR, LDEQ, and BTNEP

- Experience gained in the preliminary studies will be helpful in implementing the new follow-on project 


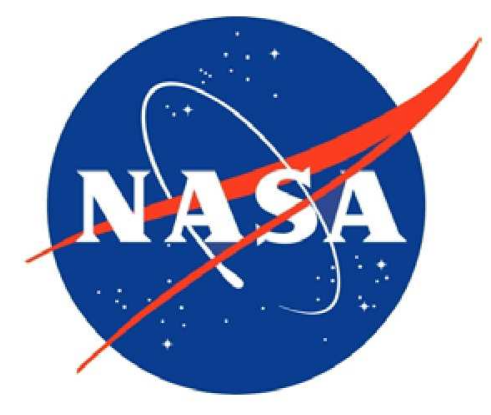

Participation in this work by Science Systems and Applications, Inc., was supported by NASA at the John C. Stennis Space Center, Mississippi, under Task Order NNS04AB54T. 